\title{
Sistem Informasi Reservasi Makul untuk Optimalisasi Kartu Rencana Studi
}

\author{
Courses Reservation Information System for Optimization of Study Plan Card \\ Tutik Khotimah*1, Arief Susanto ${ }^{2}$ \\ ${ }^{1,2}$ Program Studi Teknik Informatika, Fakultas Teknik, Universitas Muria Kudus \\ Jl. Lingkar Utara, Gondang Manis, Bae Kudus, Telp (0291) 443844 \\ e-mail: *11 tutik.khotimah@umk.ac.id, ${ }^{2}$ arief.susanto@umk.ac.id
}

\begin{abstract}
Abstrak
Kegiatan akademik di Perguruan Tinggi biasanya diawali dengan adanya pengambilan Kartu Rencana Studi (KRS). Masalah yang sering dihadapi dalam kegiatan ini adalah jadwal bentrok dan kelas penuh. Hal ini mengakibatkan mahasiswa tidak dapat mengambil mata kuliah yang dibutuhkan. Masalah ini membuktikan bahwa penentuan kebutuhan kelas pada masingmasing mata kuliah yang ditawarkan belum optimal. Untuk itu, perlu adanya sistem reservasi mata kuliah yang dapat merekam berapa jumlah mahasiswa yang memesan mata kuliah pada setiap mata kuliah yang ditawarkan per semester. Sistem ini dirancang dengan menggunakan Data Flow Diagram dan Entity Relationship Diagram. Sedangkan bahasa pemrograman php digunakan untuk menghasilkan aplikasi dengan database MySQL. Keluaran dari sistem dapat digunakan untuk optimalisasi penentuan kelas yang harus dibuka pada saat KRS.
\end{abstract}

Kata kunci—Sistem Informasi, Reservasi Makul, KRS, php, MySQL

Abstract
Academic activities in universities in college usually begins with taking Study Plan Card. The problem often experienced in this activities are conflicting schedules and class quota is full. This problem resulted the college student can not take the required courses.This issue proves that identifying the needs of each class on the courses being offered have not been optimal. Therefore, Reservation Courses Information Systems are need to record college student that reserve course. The system is designed by Data Flow Diagram and Entity Relationship Diagram. The programming language is php and database is MySQL. The output of the system can be used to optimize the grading should be opened at the time a taking Study Plan Card

Keywords - Information System, Reservation Courses, Study Plan Card, php, MySQL

\section{PENDAHULUAN}

Kegiatan akademik di Perguruan Tinggi biasanya diawali dengan adanya pengambilan Kartu Rencana Studi (KRS). KRS adalah rencana studi mahasiswa yang berisi daftar mata kuliah yang akan ditempuh selama satu semester. Pengambilan KRS harus mendapatkan persetujuan Dosen Wali atau Pembimbing Akademik (PA). KRS model lama (KRS offline) berupa lembar kertas berisi daftar mata kuliah yang akan ditempuh oleh mahasiswa dan diisi secara manual dengan persetujuan Dosen PA melalui tatap muka secara langsung. Beberapa penelitian telah mengembangkan sistem KRS manual menjadi terkomputerisasi. Seperti penelitian yang dilakukan oleh BE Purnama yang menggunakan paket pemrograman CA Clipper 5.2 dengan sistem operasi DOS untuk menangani KRS dan KHS pada Universitas Surakarta[1]. Dalam sistem KRS yang dikembangkan oleh Purnama, mahasiswa hanya memilih mata kuliah saja tanpa memilih kelas, dosen, dan jadwal. Sistem seperti ini hanya dapat diterapkan untuk mata kuliah yang hanya dibuka dengan 1 kelas saja sehingga pengelolaan 
jadwal lebih sederhana. Penelitian selanjutnya dilakukan oleh A. Baraja yang mengembangkan sistem untuk KRS, KHS, dan Keuangan dengan Visual Basic 6.0 dan DBMS MySQL [2]. Hampir sama dengan penelitian yang dilakukan oleh Purnama, sistem KRS tidak memfasilitasi mahasiswa untuk memilih kelas, dosen, dan jadwal. Berbeda dengan KRS offline, KRS model baru (KRS online) diisi dengan menggunakan aplikasi secara online melalui internet. Persetujuan dari dosen PA juga dilakukan secara online pula. A. Ristyabudi dan H. Thamrin mengembangkan KRS online dengan menerapkan teknologi Single Page Application menggunakan AngularJS[3].

KRS online merupakan salah satu bagian dari sistem informasi akademik. Di beberapa Perguruan Tinggi, seperti di Universitas Muria Kudus, pengambilan mata kuliah dalam KRS online dilakukan dengan cara memilih kelas dan jadwal yang telah disediakan oleh sistem. Setiap kelas mata kuliah dibatasi oleh kuota. Apabila kuota habis, maka mahasiswa tidak dapat mengambil kelas tersebut karena kelas penuh. Mahasiswa dapat mengambil mata kuliah yang sama dengan kelas dan jadwal yang berbeda. Kegiatan seperti ini memungkinkan satu orang mahasiswa dapat mengambil mata kuliah pada satu semester dengan kelas yang berbeda-beda. Padahal dalam sistem penjadwalan, kelas yang sama untuk mata kuliah yang berbeda dalam semester yang sama tidak akan berbentrokan, tetapi kelas yang berbeda memiliki kemungkinan terjadi bentrokan jadwal.

Ketika mahasiswa menemukan jadwal bentrok, maka mahasiswa akan mencoba memilih kelas lain yang dibuka untuk mata kuliah yang sama. Namun tidak menutup kemungkinan, kelas tersebut telah memenuhi kuota peserta kelas sehingga tidak dapat diambil. Salah satu solusi adalah dengan menambah kuota peserta kelas pada kelas yang tidak mengalami jadwal bentrok. Dapat juga dibuka kelas baru untuk mata kuliah yang sama. Namun, solusi-solusi ini menimbulkan masalah baru, yaitu peserta kelas menjadi berlebihan sehingga memberi efek pada perkuliahan yang kurang optimal. Selain itu, akan terjadi ketidakmerataan kelas: ada kelas yang kelebihan peserta, ada kelas yang kekurangan peserta, bahkan ada kelas yang harus ditutup karena tidak memiliki peserta. Masalah ini membuktikan bahwa penentuan kebutuhan kelas pada masing-masing mata kuliah yang ditawarkan belum optimal.

Untuk itu, perlu adanya sistem reservasi mata kuliah yang dapat digunakan untuk mendata mahasiswa dan mata kuliah apa saja yang akan diambil oleh mahasiswa tersebut. Sistem ini mengatasi kekurangan dari sistem KRS yang ada di UMK dengan melakukan pendataan kebutuhan mahasiswa terhadap mata kuliah yang akan diambil. Dari sistem ini, dapat diketahui jumlah mahasiswa yang akan mengambil mata kuliah dari masing-masing mata kuliah yang ditawarkan. Dari informasi ini, dapat ditentukan berapa kelas yang dibutuhkan untuk setiap mata kuliah yang ditawarkan sehingga kelas yang dibuka lebih optimal. Aplikasi dibangun dengan pemrograman php dan database MySQL. Untuk memperingan pengaksesan aplikasi, sistem ini menerapkan teknologi AJAX (Asynchronous JavaScript And XML) menggunakan JQuery.

\section{METODE PENELITIAN}

Secara umum, gambaran penelitian dapat dilihat pada gambar 1. Sedangkan langkahlangkah penelitian dapat dilihat pada gambar 2 . 


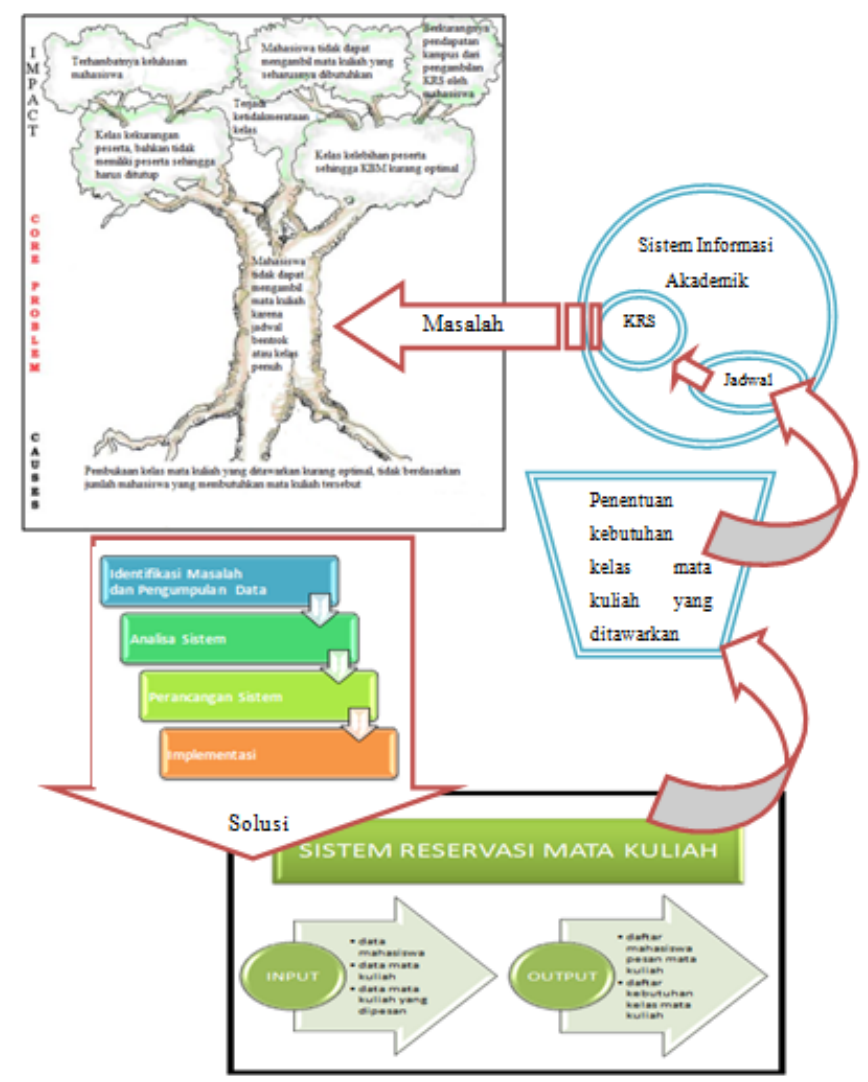

Gambar 1 Gambaran Penelitian

Langkah-langkah penyelesaian masalah dapat dilihat pada gambar 2. Penelitian ini merupakan penelitian rekayasa perangkat lunak yang dilaksanakan dengan metode Software Development Life Cycle (SDLC). Ada pun tahapannya adalah sebagai berikut:

1. Identifikasi dan Pengumpulan data

Metode yang digunakan dalam pengumpulan data adalah:

a. Observasi

Observasi adalah pengumpulan data yang dilakukan dengan melakukan pengamatan pada objek studi, yaitu proses pengambilan mata kuliah dalam sistem KRS online yang diterapkan pada Program Studi Teknik Informatika Universitas Muria Kudus.

b. Wawancara (Interview)

Wawancara dilakukan dengan melakukan tanya jawab kepada pihak-pihak yang terlibat, seperti Kepala Program Studi, Dosen PA, dan mahasiswa.

c. Dokumentasi

Metode dokumentasi dilakukan dengan mengumpulkan dokumen yang berkaitan dengan KRS, seperti mata kuliah, jadwal, mahasiswa, dsb.

2. Analisis

Pada tahap analisis, kegiatan yang dilakukan adalah sebagai berikut. Pertama melakukan analisis terhadap objek studi, yaitu proses pengambilan mata kuliah dalam sistem KRS online yang diterapkan pada Program Studi Teknik Informatika Universitas Muria Kudus. Kegiatan ini dilakukan untuk mengetahui bagaimana sistem KRS online yang sedang berjalan di Program Studi Teknik Informatika Universitas Muria Kudus dan masalah apa saja yang terjadi. Setelah merumuskan masalah yang ada, langkah selanjutnya adalah mencari solusi. Setelah menentukan solusi yang dipilih, langkah berikutnya adalah melakukan analisis kebutuhan, baik kebutuhan data dan informasi, mau pun kebutuhan infrastruktur yang diperlukan. 
3. Perancangan

Perancangan yang dilakukan antara lain: perancangan sistem, perancangan database, dan perancangan interface. Perancangan sistem dilakukan untuk menggambarkan alur proses dari sistem informasi reservasi mata kuliah. Perancangan sistem dilakukan dengan menggunakan Data Flow Diagram (DFD) [4]. Sedangkan perancangan database dilakukan untuk menghasilkan tempat penyimpanan data yang sesuai dengan kebutuhan. Perancangan database diawali dengan membuat Entity Relationship Diagram (ERD)[5] kemudian melakukan transformasi ke tabel. Pada perancangan interface, yang dilakukan adalah menyusun tampilan form untuk proses penginputan data, seperti: form mata kuliah, form reservasi. Selain itu juga merancang tampilan dari informasi yang ingin dihasilkan dari sistem, seperti informasi jumlah mahasiswa yang memesan masing-masing mata kuliah pada mata kuliah yang ditawarkan setiap semester.

4. Implementasi

Pada tahap implementasi yang dilakukan adalah mengubah rancangan-rancangan yang telah didefinisikan dengan melakukan koding menggunakan bahasa pemprograman PHP. Rancangan database juga diubah menjadi sebuah basis data yang dapat digunakan untuk menyimpan data sesuai kebutuhan. Pada sistem ini, basis data dibuat dengan MySQL. Sistem ini juga menerapkan teknologi AJAX (Asynchronous JavaScript And XML) menggunakan JQuery.

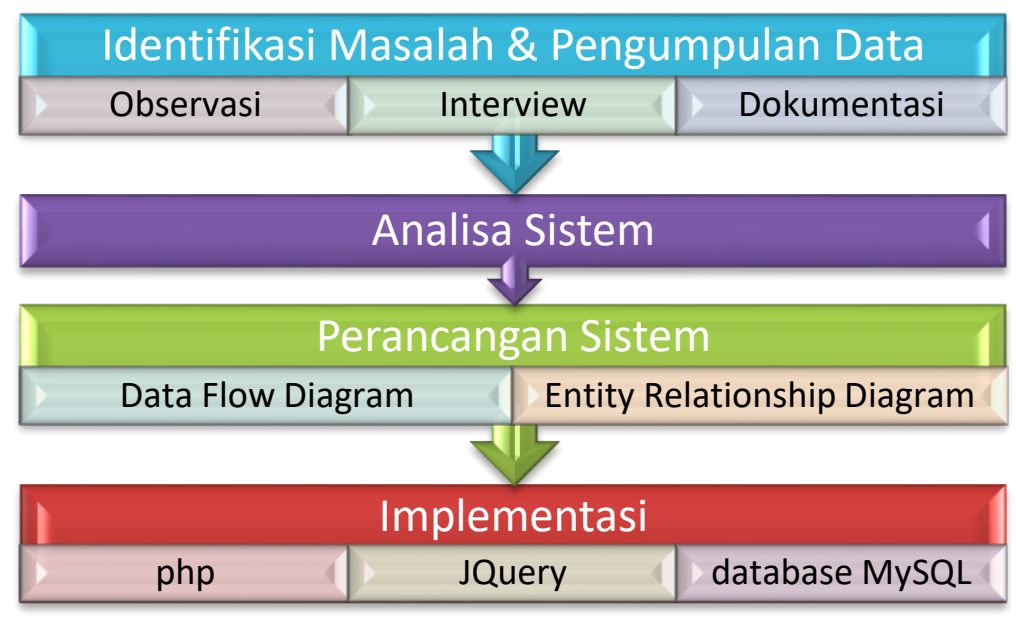

Gambar 2 Langkah Penelitian

\section{HASIL DAN PEMBAHASAN}

Prosedur pengambilan KRS pada sistem yang sedang berjalan di Program Studi Teknik Informatika Universitas Muria Kudus ditunjukkan pada Gambar 3 


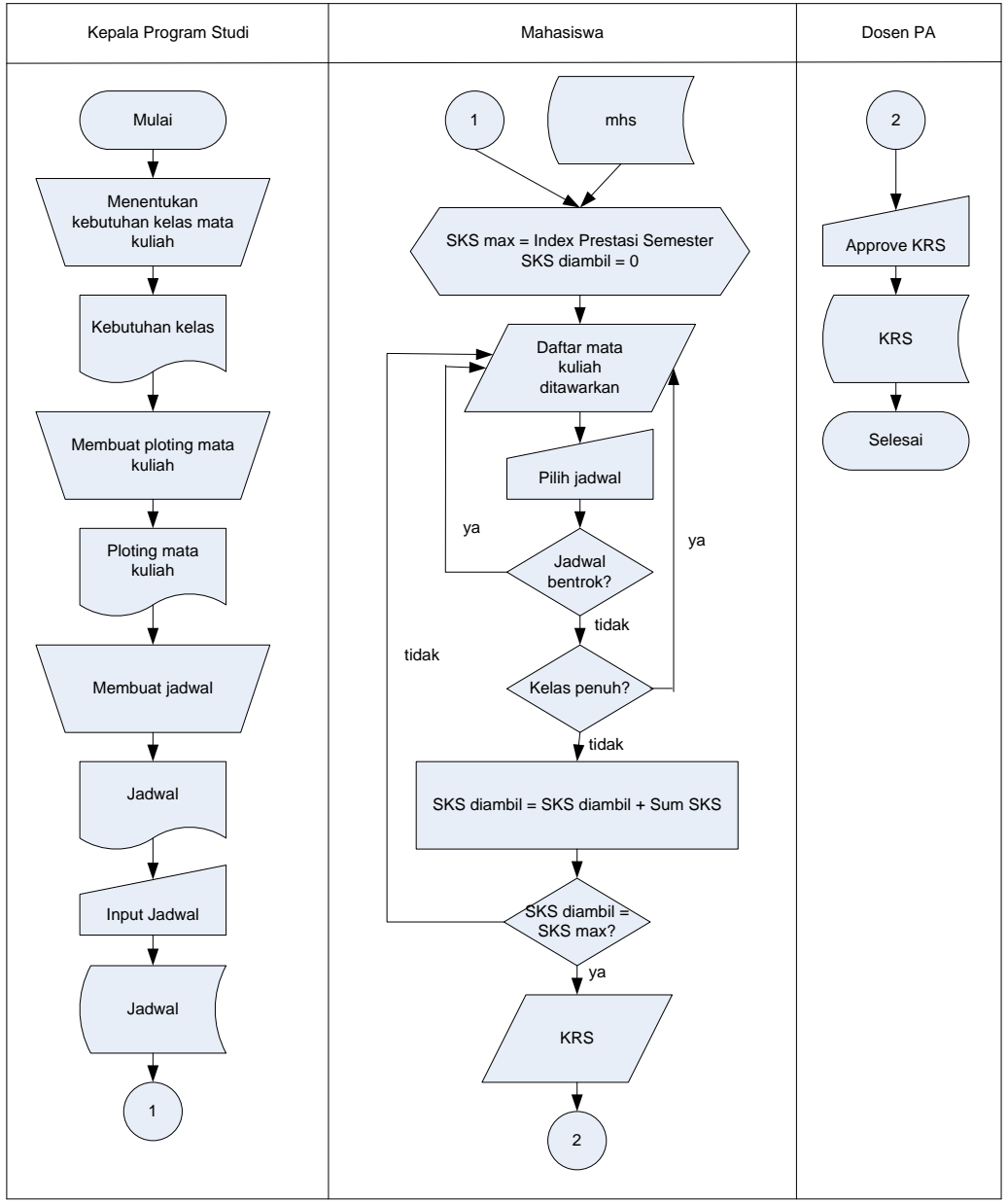

Gambar 3 Flow of Document KRS

Gambaran sistem yang sedang berjalan (sistem lama) dan sistem yang disarankan (sistem baru) dapat dilihat pada Gambar 4

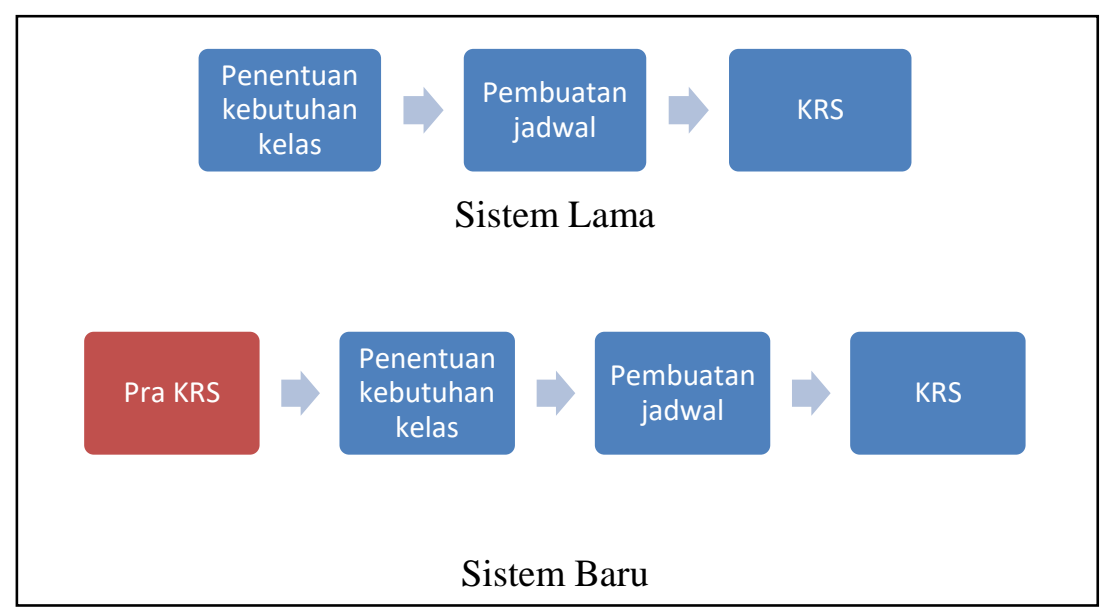

Gambar 4 Perbandingan Sistem Lama dan Sistem Baru

Sistem reservasi mata kuliah atau sistem pra KRS dirancang dengan menggunakan 2 tools, yaitu Data Flow Diagram (DFD) dan Entity Relationship Diagram (ERD). DFD 
menggambarkan jalannya sebuah sistem, sedangkan ERD menggambarkan keterkaitan antar entitas dalam sistem.

Dalam DFD, ada 2 diagram yang dirancang, yaitu Context Diagram dan Data Flow Diagram Level 0. Context Diagram menggambarkan alur sistem secara garis besar, sedangkan DFD Level 0 menggambarkan sistem dan keterlibatannya dengan storage. Berikut ini adalah Context Diagram yang ditunjukkan pada Gambar 5 dan Data Flow Diagram Level 0 yang ditunjukkan pada Gambar 6

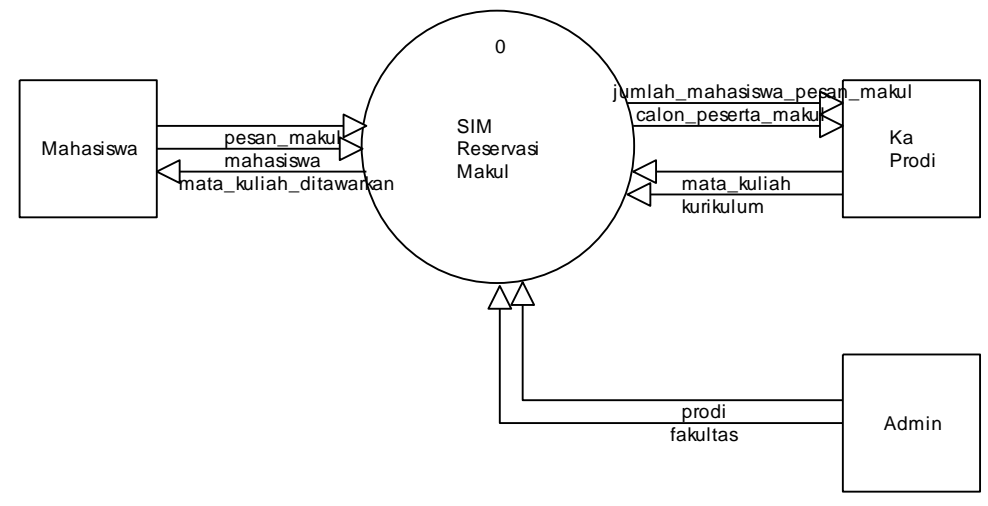

Gambar 5 Context Diagram Sistem Reservasi Makul

Pada Gambar 5, terdapat 3 external entity yang terlibat dalam sistem, yaitu Admin, Ka Prodi, dan Mahasiswa. Admin memasukkan data fakultas dan prodi ke dalam sistem. Ka Prodi memasukkan data kurikulum dan mata kuliah ke dalam sistem. Mahasiswa memasukkan data mahasiswa ke dalam sistem. Mahasiswa memperoleh informasi mata kuliah yang ditawarkan dari sistem, kemudian mahasiswa memasukkan transaksi pemesanan mata kuliah ke dalam sistem. Transaksi ini akan diolah oleh sistem sehingga menghasilkan informasi calon peserta makul dan jumlah mahasiswa pesan makul.

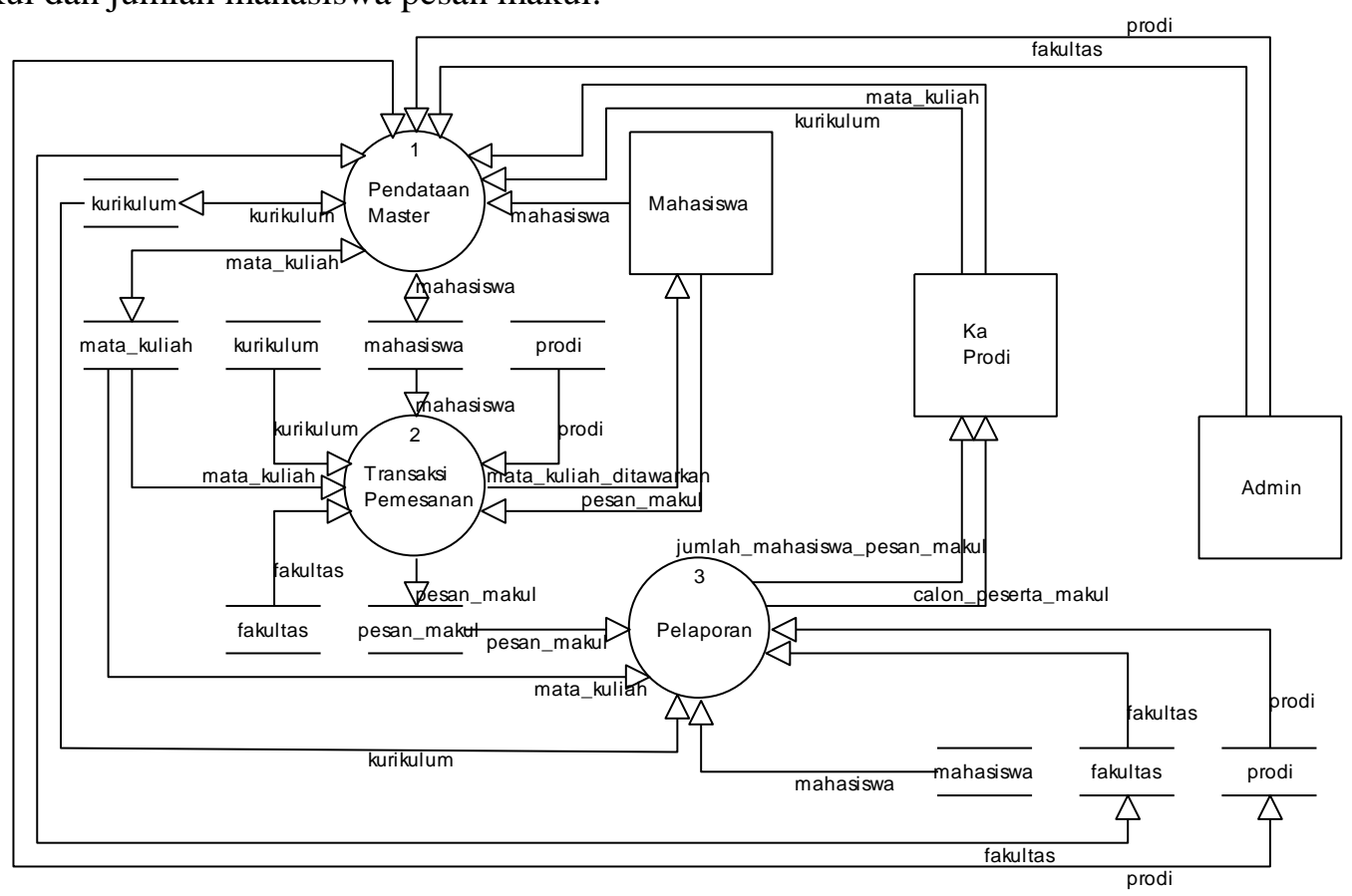

Gambar 6 DFD Level 0 Sistem Reservasi Makul 
Pada DFD Level 0 yang ditunjukkan pada Gambar 5, sistem dipecah menjadi 3 proses, yaitu Proses Pendataan Master, Proses Transaksi Pemesanan, dan Proses Pelaporan. Storage yang digunakan ada 6 yaitu: fakultas, prodi, kurikulum, mata_kuliah, mahasiswa, dan pesan_makul.

Pada Proses Pendataan Master, ada 3 external entity yang terlibat yaitu Admin, Ka Prodi, dan Mahasiswa. Admin memberikan masukan ke dalam Proses Pendataan Master berupa data fakultas dan data prodi. Data fakultas disimpan ke storage fakultas dan data prodi disimpan ke storage prodi. Ka Prodi memberikan masukan ke dalam Proses Pendataan Master berupa data kurikulum dan data mata kuliah. Data kurikulum disimpan ke storage kurikulum dan data mata kuliah disimpan ke storage mata kuliah. Mahasiswa memberikan masukan ke dalam Proses Pendataan Master berupa data mahasiswa yang disimpan ke storage mahasiswa.

Pada Proses Transaksi Pemesanan, external entity yang terlibat adalah Mahasiswa. Proses ini memberikan keluaran berupa informasi mata kuliah ditawarkan kepada Mahasiswa. Informasi ini diperoleh dari storage fakultas, prodi, kurikulum, dan mata kuliah dengan melihat data mahasiswa dari external entity yang terlibat. Dari informasi ini, Mahasiswa dapat memberikan masukan berupa data pesan makul yang akan disimpan di storage pesan makul.

Proses Pelaporan melibatkan external entity berupa Ka Prodi. Proses ini memberikan keluaran berupa informasi calon peserta makul dan jumlah mahasiswa pesan makul. Informasiinformasi ini diperoleh dari storage fakultas, prodi, kurikulum, makul, mahasiswa, dan pesan makul.

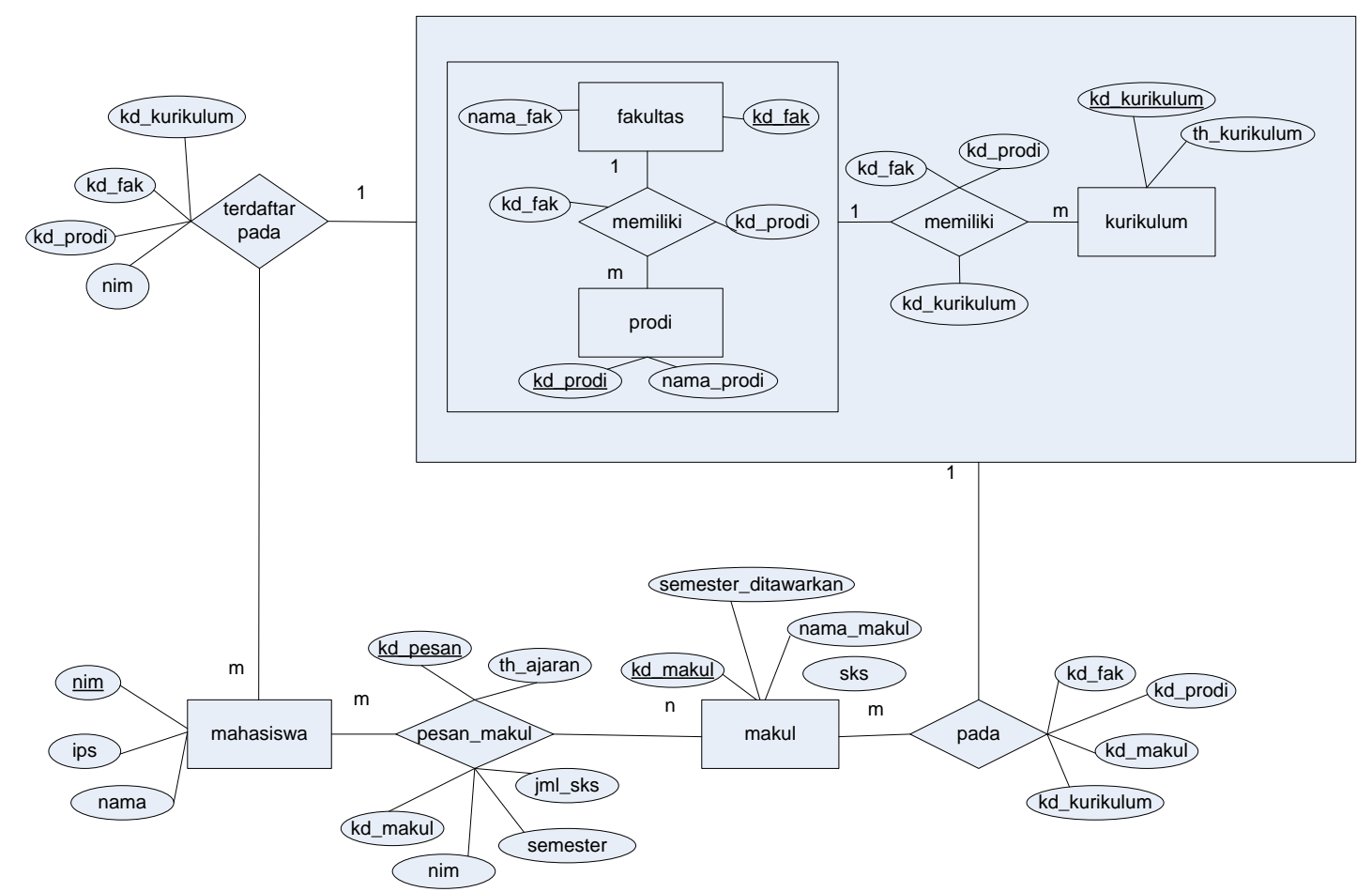

Gambar 7 ERD Sistem Reservasi Makul

Gambar 7 menunjukkan Entity Relationship Diagram (ERD) Sistem Reservasi Makul. Dalam ERD, ada 5 entitas yang terdiri dari fakultas, prodi, kurikulum, makul, dan mahasiswa. Entitas fakultas memiliki atribut berupa kd_fak dan nama_fak. Entitas prodi memiliki atribut kd_prodi dan nama_prodi. Entitas kurikulum memiliki atribut kd_kurikulum dan th_kurikulum. Entitas fakultas dan entitas prodi memiliki hubungan agregasi sehingga dari hubungan entitas fakultas dan entitas prodi menghasilkan entitas baru. Entitas ini memiliki hubungan agregasi juga dengan entitas kurikulum. Dari hubungan ini menghasilkan entitas baru yang lebih besar. 
Entitas makul memiliki atribut kd_makul, nama_makul, sks, dan semester_ditawarkan. Entitas mahasiswa memiliki atribut nim, nama, dan ips. Entitas makul memiliki hubungan dengan entitas yang dihasilkan dari hubungan agregasi antara entitas fakultas, entitas prodi, dan entitas kurikulum. Entitas mahasiswa juga memiliki hubungan dengan entitas yang dihasilkan dari hubungan agregasi antara entitas fakultas, entitas prodi, dan entitas kurikulum. Sedangkan entitas mahasiswa memiliki hubungan dengan makul berupa pesan_makul. Hubungan ini adalah hubungan many to many. Atribut yang dimiliki oleh relasi pesan_makul antara lain: kd_pesan, th_ajaran, nim, kd_makul, semester, jml_sks.

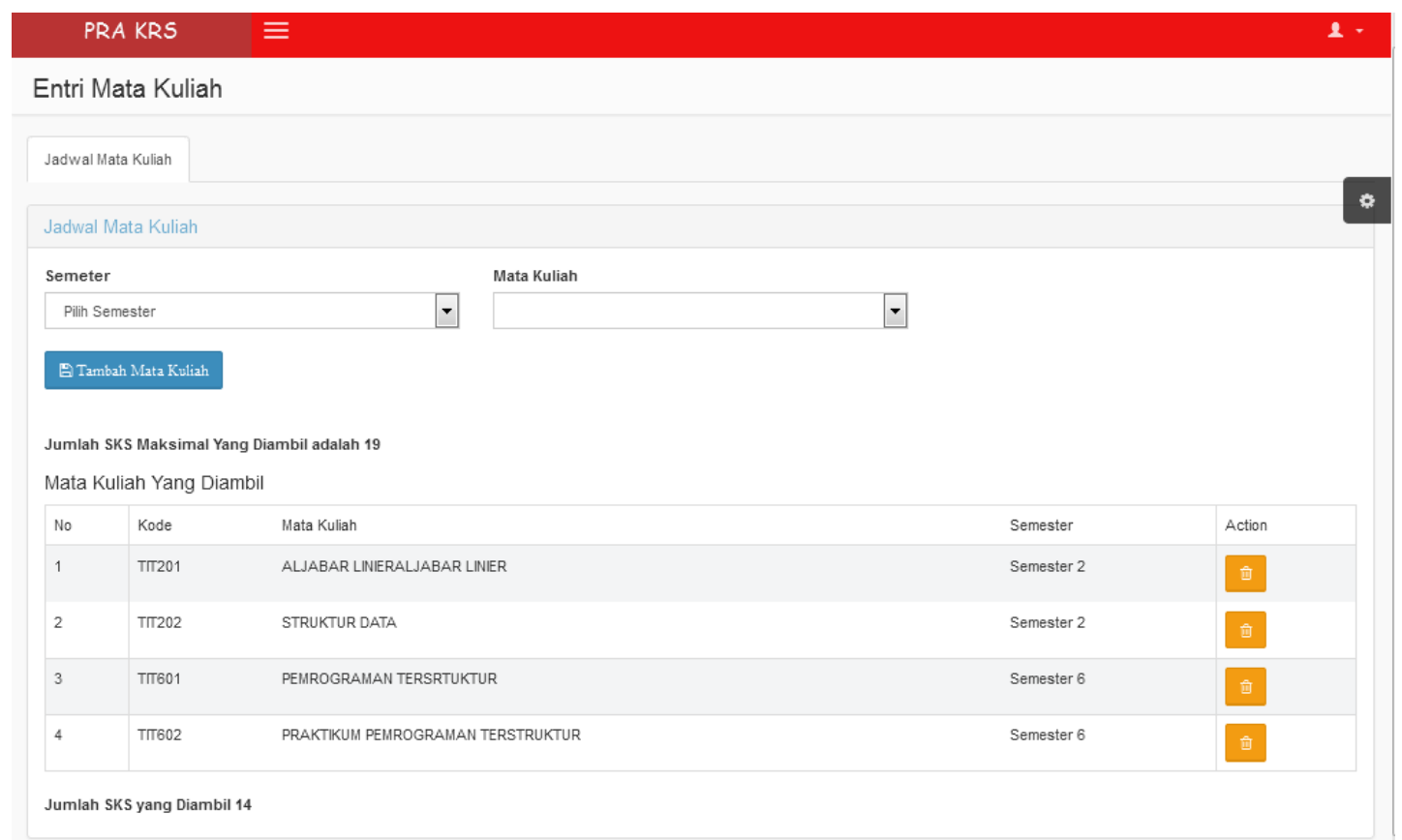

\section{Gambar 8 Form Transaksi Pemesanan Mata Kuliah}

Gambar 8 menunjukkan form transaksi pemesanan mata kuliah. Form ini adalah form utama dari sistem. Data yang dimasukkan oleh mahasiswa akan disimpan dalam 2 tabel yaitu tabel transaksi_pesan dan tabel detiltransaksi_pesan. Ada pun output dari sistem ditunjukkan pada Gambar 9, yaitu laporan pemesanan mata kuliah yang berisi jumlah mahasiswa yang memesan masing-masing mata kuliah yang ditawarkan.

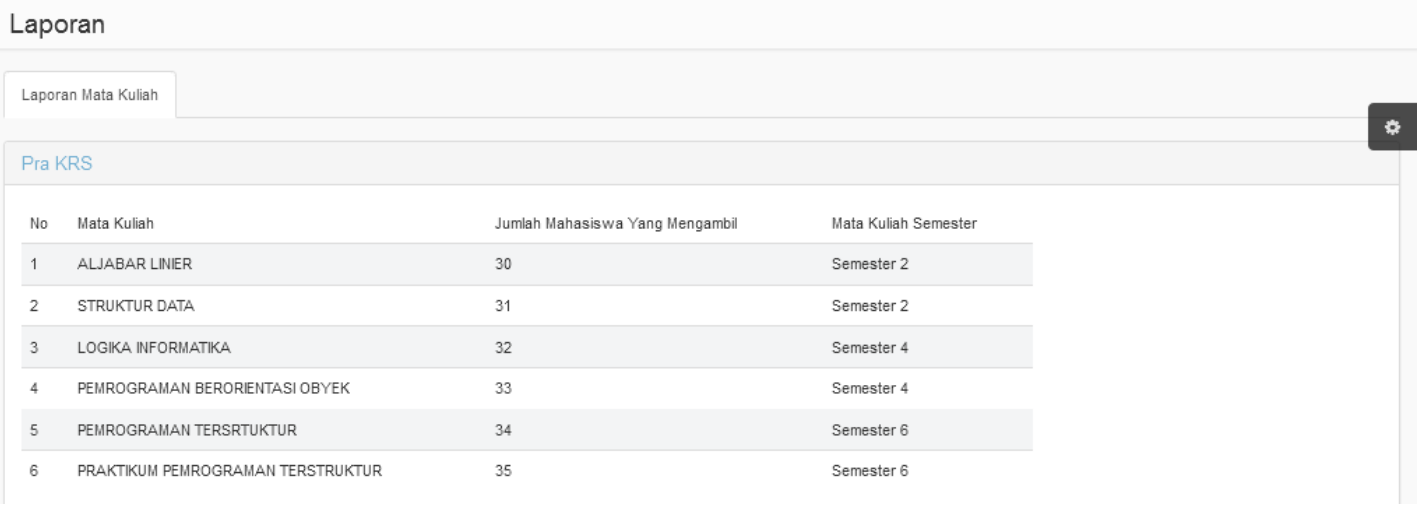

Gambar 9 Laporan Pemesanan Mata Kuliah 


\section{KESIMPULAN}

Dari hasil penelitian dapat disimpulkan bahwa: (1) Telah dihasilkan "Sistem Reservasi Mata Kuliah" atau disebut juga Sistem Pra KRS. Sistem ini merupakan prototipe dari pemecahan masalah dalam proses pengambilan KRS yang ada di Program Studi Teknik Informatika Universitas Muria Kudus.(2)Karena merupakan prototipe, sistem ini belum diintegrasikan dengan data yang ada pada database akademik dari sistem portal yang digunakan di Universitas Muria Kudus. (3) Sistem ini dapat menghasilkan keluaran berupa jumlah mahasiswa yang memesan mata kuliah sehingga Kepala Program Studi dapat menentukan jumlah kelas yang dibutuhkan masing-masing mata kuliah yang ditawarkan. (4) Sistem ini tidak berlaku untuk mahasiswa semester pertama.

\section{SARAN}

Saranuntuk penelitian lebih lanjut antara lain: sistem dapat diintegrasikan dengan sistem portal akademik yang digunakan oleh Universitas Muria Kudus melalui penyesuaian database.

\section{DAFTAR PUSTAKA}

[1] Purnama, Bambang Eka, 2011, "Perancangan Sistem KRS dan KHS Universitas Surakarta", Jurnal Speed - Sentra Penelitian Engineering dan Edukasi - , Vol 3, No 1, hal 62-70

[2] Baraja, Abdillah, 2009, "Implementasi Sistem Informasi Akademik Universitas Surakarta", Jurnal Speed - Sentra Penelitian Engineering dan Edukasi - , Vol 1, No 2, hal 10-19

[3] Ristyabudi, Aryani, dan Husni Thamrin, 2016, "Penerapan Single Page Application pada Proses Pengisian Online Data Rencana Studi Mahasiswa", Khazanah Informatika Jurnal Ilmu Komputer dan Informatika, Vol 2, No 1, hal 1-9

[4] Jogiyanto, HM. 2005. Analisis \& Desain. ANDI : Yogyakarta.

[5] Morgan, Kaufmann, 2006. Database Modeling And Design. USA 